\title{
EFFECT OF DIETARY INCLUSION OF WHOLE SUNFLOWER SEEDS ON FEEDING LACTATING ZARAIBI GOATS: I. ON DIGESTIBILITY COEFFICIENTS, RUMEN FUNCTION AND LIVE BODY WEIGHT \\ Abdelhamid, A. M.* ; A. E. Abdel-Khalek* ; T. A. M. Ashmawy**; Faten F. Abou Ammou ${ }^{\star \star}$ and Heba A. El-Sanafawy**. \\ * Anim. Prod. Dept., Fac. Agric., Mansoura Univ. \\ ** Anim. Prod. Res. Inst., Agric. Res. Center
}

\begin{abstract}
A total of 30 Zaraibi lactating goat does $(42.46 \pm 0.86 \mathrm{~kg}$ LBW and $4-5$ years of age) were used in this study to investigate the effect of partially replacing concentrate feed mixture (CFM) containing cotton seed cake in the diet by two levels of sunflower seeds (SFS), being $15 \%\left(\mathrm{G}_{2}\right)$ and $20 \%\left(\mathrm{G}_{3}\right)$ on chemical composition, digestibility coefficients, rumen liquor parameters and live body weight of Zaraibi goats. At the last month of pregnancy, goat does were divided into three similar groups (10 in each). Goat does in the $1^{\text {st }}$ group $\left(\mathrm{G}_{1}\right.$, control) were fed a basal ration containing $25 \% \mathrm{CFM}$ and $75 \%$ fresh berseem (FB) during winter feeding or $50 \% \mathrm{CFM}$ and $50 \%$ berseem hay $(\mathrm{BH})$ during summer feeding. During an experimental period from $30 \mathrm{~d}$ pre-partum up to the next mating season, does in all groups were biweekly weighed. Two digestibility trials were conducted during the suckling period (winter feeding) and mid of the lactation period (summer feeding). Results revealed that contents of $\mathrm{EE}$ and $\mathrm{OM} \%$ were higher, while contents of $\mathrm{DM}, \mathrm{CP}$ and ash were lower in SFS treatment groups than in control group. However, contents of CF and NFE \% were nearly similar in SFS and CFM treatment groups. Winter feeding was characterized by higher CP (about 15 vs. 13\%) and lower CF (about 12 vs. 16\%) than summer feeding. By increasing level of SFS from 15 to $20 \%$, only digestibility coefficients (DCs) of $\mathrm{DM}, \mathrm{OM}$ and $\mathrm{EE}$ increased $(\mathrm{P}<0.05)$ during winter feeding; however, DCs of all nutrients, except of $C P$, increased $(P<0.05)$ during summer feeding. During the winter and summer feeding, nutritive value of experimental rations as TDN increased $(P<0.05)$ by increasing level of SFS, while nutritive values as TDN or DCP was higher $(\mathrm{P}<0.05)$ for both SFS levels, being the highest for $20 \%$ SFS diet. Inclusion of both SFS-levels during winter feeding increased $(\mathrm{P}<0.05) \mathrm{pH}$ value and decreased concentration of VFAs, but did not affect ammonia concentration in ruminal liquor $(\mathrm{RL})$. Only $20 \%$ SFS diet decreased $(\mathrm{P}<0.05) \mathrm{pH}$ value and increased concentration of VFAs and ammonia in RL sampled before or post-feeding during summer feeding. The differences in live body weight of does among the experimental groups and within each group were not significant $(P \geq 0.05)$ at different experimental periods. It could be concluded that replacing $20 \%$ of CFM by sunflower seed has beneficial effects on digestibility coefficient and nutritive values without marked change in rumen liquor parameters and goat performance.
\end{abstract}

Keywords: Goats, sunflower, digestibility, nutritive values, rumen, performance.

\section{INTRODUCTION}

Goat is one of the most important livestock species in rural areas. In Sudan, Pakistan, Turkey, Egypt and Tunisia researches showed that goats 
are reared for their meat, milk or both meat and milk (Gaddour et al., 2007; El-Hassan El-Abid et al., 2008; Arain et al., 2010 and Mousa, 2011).

Sunflower is popular with small-scale communal farmers because it is an easy crop to produce. The general practice is to plant sunflower and leave it to grow on its own with little inputs and weeding. Sunflower is known to be an efficient user of residual fertilizer because of its extensive root system (Chiduza et al., 1995). Therefore the crop does well in a rotation following a well-fertilized crop.

Protein is the most expensive feed ingredient in animal ration and there was always shortage in its supply particularly in developing countries. This shortage is very critical in both human and animal nutrition (Yagoub and Babiker, 2009). Traditionally, the farmers have been using cottonseed cakes for feeding their livestock as a source of vegetable protein and its prolonged use can affect the fertility of these animals (Zahid et al., 2003). Earlier investigators (Ahmed et al., 2004 and Garcia et al., 2004) indicated that sunflower meal has good effect on performance; yet, the cost of sunflower meal based rations was the lowest.

To cover the required nutrients for goats, energy and protein of their feed should be increased, as these dairy animals have a small rumen capacity. Green fodders, including silage, high in fiber and/or water are low energy and protein components. On the other hand, grain, seed fats (sunflower, soybeans) contribute to increased energy intake of goats and flours of defatted oilseeds in the diet increase protein intake (Antunac et al., 2001).

Ruminants have unique ability to utilize the fibrous material through anaerobic fermentation (Kibria et al., 1991); therefore, sunflower seed meal (SFM) can be efficiently used as a sole source of supplemental protein for ruminants (Lardy and Anderson, 2002). Cottonseed cakes (CSC) are being traditionally used in the feed of dairy animals. However, limited supply and seasonal availability of CSC result in high price. On the other hand, SFM is cheaper protein source and can be used in ruminants feed supplements (Yunus et al., 2004).

The present study was conducted to investigate the effect of partially replacing concentrate feed mixture (CFM) containing cottonseed cake in the diet with two levels of sunflower seed (15 and $20 \%$ ) on chemical composition, digestibility coefficients, rumen liquor parameters and live body weight of Zaraibi goats.

\section{MATERIALS AND METHODS}

This study was carried out at Sakha Experimental Station, belonging to the Animal Production Research Institute, Agricultural Research Center, Ministry of Agriculture, in cooperation with Department of Animal Production, Faculty of Agriculture, Mansoura University during the period from December 2008 to December 2010.

\section{Animals and experimental groups:}

Total of 30 local breed (Zaraibi) goats $(42.46 \pm 0.86 \mathrm{~kg} \mathrm{LBW}$ and $4-5$ years of age) were used in this study. At the late stage of pregnancy (last 
month of pregnancy, January 2009), goat does were divided into three similar groups (10 in each) according to their LBW and age. Goat does in the $1^{\text {st }}$ group $\left(\mathrm{G}_{1}\right.$, control) were fed a basal ration contained $25 \% \mathrm{CFM}$ and $75 \%$ fresh berseem (FB, Trifloium alexanrium) during winter feeding period or $50 \%$ CFM and $50 \%$ berseem hay $(\mathrm{BH})$ during summer feeding period according to the NRC feeding requirements (NRC, 2001) for production of $1-2 \mathrm{~kg}$ milk/head/day. The CFM consisted of cotton seed cake, linseed cake, yellow corn, wheat bran, molasses, calcium chloride and common salt. The daily feed intake per doe composed of $1.250 \mathrm{~kg}$ CFM and $4 \mathrm{~kg} \mathrm{FB}$ or $1.3 \mathrm{~kg} \mathrm{BH}$ for each doe. In ration of the $2^{\text {nd }}$ group $\left(\mathrm{G}_{2}\right)$ and $3^{\text {rd }}$ group, 15 and $20 \%$ of CFM of the control ration was replaced by $15 \%$ and $20 \%$ SFS (Halianthus annuus) on DM basis, respectively.

After kidding, during the suckling period up to $90 \mathrm{~d}$ post-partum, does were suckled by their kids produced in each group. However, during milking period, machine milking was applied for all does. All does were kept under similar management conditions.

\section{Experimental procedures:}

During an experimental feeding period (from $30 \mathrm{~d}$ pre-partum up to the next mating season), does in all groups were biweekly weighed. Two digestibility trials were conducted during the experimental period to determine nutrients digestion coefficient and nutritive values of the experimental rations, during the suckling period (winter feeding) and mid of the lactation period (summer feeding). Three does from each group were chosen to determine digestibility coefficients and nutritive values of the experimental rations using acid insoluble ash (AIA) as a natural marker according to Van Keulen and Young (1977). Feces samples were taken from the rectum of each doe twice daily at 12 hour-interval during the collection period ( 5 days). Representative samples of the tested feedstuffs were taken at the beginning; middle and end of the collection period as well as samples of feces were taken to determine chemical analysis according to A.O.A.C. (1990).

During the digestibility trials, rumen liquor was obtained via rubber stomach tube using gentle mouth suction. Rumen liquor was sampled before feeding and at 3 and 6 hours after feeding. The samples were filtered through two layers of surgical gauze. Values of ruminal $\mathrm{pH}$ were determined using a pH meter (SA-720, Orion Research, Boston, MA) immediately after sampling. Then, $1 \mathrm{ml}$ of saturated $\mathrm{HgCl}_{2}$ solution was added to inhibit microbial fermentation. After acidification of rumen liquor samples using concentrated orthophosphoric acid and $0.1 \mathrm{~N}$ hydrochloric acid, concentration of volatile fatty acids (VFAs) was determined by steam distillation methods as described by Warner (1964). However, determination of $\mathrm{NH}_{3}-\mathrm{N}$ concentration was carried out according to Conway and O'Malley (1957).

\section{Statistical analysis:}

The data were subjected to statistical analysis using General Linear Models Procedures (GLMP) adapted by SPSS (2004) for windows for user's guide with one-way ANOVA. Duncan test within program SPSS was done to determine the level of significance between the means. 


\section{RESULTS AND DISCUSSION}

\section{Chemical composition for tested rations:}

Data presented in Table (1) show that contents of EE and OM were higher, while contents of DM, CP, and ash were lower in SFS than in CFM. Increasing OM in SFS as compared to CFM was due to ash content in SFS and CFM. However, contents of CF and NFE were nearly similar in SFS and $\mathrm{CFM}$. The present results indicated that all experimental rations during winter or summer feeding were isonitrogenous and isocaloric, but winter feeding was characterized by higher CP (about 15 vs. 13\%) and lower CF (about 12 vs. $16 \%$ ) than those of summer feeding (Table 1). The calculated chemical composition is in agreement with the chemical composition of experimental rations obtained by Landau et al. (1995) in Damascus and Mamber goats browsing a Mediterranean shrub land. Average crude protein (CP) in treated groups was about $15 \mathrm{~g} / \mathrm{kg} \mathrm{DM}$ with feeding fresh berseem and $13.0 \mathrm{~g} / \mathrm{kg} D M$ with feeding berseem hay which had enough $\mathrm{N}$ for microbial activities in rumen (Norton et al., 1994).

Digestibility coefficients:

During winter feeding, data in Table (2) indicated that only digestibility coefficients of DM, OM and EE were significantly increased by increasing level of SFS from 15 to $20 \%$. However; during summer feeding, digestibility coefficients of DM, OM, CP, NFE, except CF were significantly $(P<0.05)$ increased by increasing level of SFS. During the winter and summer feeding, nutritive value of experimental rations as TDN showed significant $(P<0.05)$ increase by increasing level of SFS, being the highest for ration containing $20 \%$ SFS. However, the effect of SFS diets on nutritive values as TDN and DCP was significant $(\mathrm{P}<0.05)$ during summer feeding, being also the highest for $20 \%$ SFS diet (Table 2). These results indicated significant $(\mathrm{P}<0.05)$ improvement in digestibility coefficients of most nutrients and in nutritive values as TDN and DCP of ration, when $20 \%$ of CFM were replaced by SFS, in particular during summer feeding with berseem hay.

Table (1):Chemical composition of different feed ingredients and experimental rations.

\begin{tabular}{|c|c|c|c|c|c|c|c|}
\hline \multirow{2}{*}{ Item } & \multirow{2}{*}{$\begin{array}{l}\text { DM } \\
(\%)\end{array}$} & \multicolumn{6}{|c|}{ Chemical composition (\%) on DM basis } \\
\hline & & OM & $\mathbf{C P}$ & CF & EE & NFE & Ash \\
\hline \multicolumn{8}{|c|}{ Feed ingredients: } \\
\hline CFM & 89.95 & 87.76 & 14.40 & 7.08 & 2.40 & 63.88 & 12.24 \\
\hline SFS & 85.65 & 96.91 & 11.91 & 8.08 & 14.66 & 62.26 & 3.09 \\
\hline FB & 17.06 & 88.59 & 16.65 & 20.98 & 2.35 & 48.61 & 11.41 \\
\hline $\mathrm{BH}$ & 86.19 & 89.19 & 12.65 & 27.85 & 3.41 & 45.29 & 10.81 \\
\hline \multicolumn{8}{|c|}{ Calculated composition of winter ration (R): } \\
\hline $\mathrm{R}_{1}\left(\mathrm{G}_{1}\right)$ & 34.41 & 88.07 & 15.24 & 12.32 & 2.37 & 58.14 & 11.93 \\
\hline $\mathrm{R}_{2}\left(\mathrm{G}_{2}\right)$ & 34.26 & 89.43 & 14.86 & 12.47 & 4.20 & 57.90 & 10.57 \\
\hline $\mathrm{R}_{3}\left(\mathrm{G}_{3}\right)$ & 34.21 & 89.90 & 14.74 & 12.51 & 4.82 & 57.83 & 10.10 \\
\hline \multicolumn{8}{|c|}{ Calculated composition of summer ration (R): } \\
\hline $\mathrm{R}_{1}\left(\mathrm{G}_{1}\right)$ & 88.27 & 88.36 & 13.63 & 16.09 & 2.83 & 55.81 & 11.64 \\
\hline $\mathrm{R}_{2}\left(\mathrm{G}_{2}\right)$ & 87.91 & 89.73 & 13.25 & 16.24 & 4.66 & 55.58 & 10.27 \\
\hline $\mathrm{R}_{3}\left(\mathrm{G}_{3}\right)$ & 87.80 & 90.19 & 13.03 & 16.28 & 5.28 & 55.6 & 9.81 \\
\hline
\end{tabular}

CFM: Concentrate feed mixture. SFS: Sun flower seeds. FB: Fresh berseem. BH: Berseem hay. 
It is of interest to note that digestibility coefficients of CF were not affected significantly by level of SFS during winter or summer feeding. It was found that fiber digestibility is adversely affected by dietary fat supplementation (Jenkins, 1993). In this line, Schauff et al. (1992) found that feeding flaxseed compared with sunflower seed could result in less oil being released in the rumen, which would limit the negative effect of oil on fiber digestion. Also, it was observed that digestibility coefficients of all nutrients were higher during winter than summer feeding, except for EE digestion, which showed an opposite trend. Such finding was mainly related to differences in digestibility coefficients of nutrients of $\mathrm{FB}$ or $\mathrm{BH}$ during winter and summer feeding, respectively. This difference may be due to feed intake and that whole SFS did not contained more non-nutritive lipid (Grummer and Carroll, 1988 and Schauff and Clark, 1989). Also, Min et al. (2005) found that the response to oil seeds supplementation can be high if forage quality is low and minimal if the forage quality is high as in the FB and $\mathrm{BH}$.

Table (2): Average digestibility coefficients of nutrients and nutritive value (TDN and DCP) of the experimental rations (R).

\begin{tabular}{|l|c|c|c|c|c|c|}
\hline \multirow{2}{*}{ Item } & \multicolumn{3}{|c|}{ Winter feeding } & \multicolumn{3}{c|}{ Summer feeding } \\
\cline { 2 - 7 } & $\mathbf{R}_{\mathbf{1}}\left(\mathbf{G}_{\mathbf{1}}\right)$ & $\mathbf{R}_{\mathbf{2}}\left(\mathbf{G}_{\mathbf{2}}\right)$ & $\mathbf{R}_{\mathbf{3}}\left(\mathbf{G}_{\mathbf{3}}\right)$ & $\mathbf{R}_{\mathbf{1}}\left(\mathbf{G}_{\mathbf{1}}\right)$ & $\mathbf{R}_{\mathbf{2}}\left(\mathbf{G}_{\mathbf{2}}\right)$ & $\mathbf{R}_{\mathbf{3}}\left(\mathbf{G}_{3}\right)$ \\
\hline Digestibility coefficients (\%) of nutrient: & \\
\hline DM & $68.94^{\mathrm{c}}$ & $71.97^{\mathrm{b}}$ & $74.60^{\mathrm{a}}$ & $63.98^{\mathrm{c}}$ & $68.26^{\mathrm{b}}$ & $70.06^{\mathrm{a}}$ \\
OM & $68.94^{\mathrm{c}}$ & $71.97^{\mathrm{b}}$ & $74.60^{\mathrm{a}}$ & $63.98^{\mathrm{c}}$ & $68.26^{\mathrm{b}}$ & $70.06^{\mathrm{a}}$ \\
CP & 64.98 & 69.91 & 72.15 & $60.03^{\mathrm{b}}$ & $67.36^{\mathrm{a}}$ & $68.03^{\mathrm{a}}$ \\
CF & $54.19^{\mathrm{b}}$ & $58.91^{\mathrm{a}}$ & $62.87^{\mathrm{a}}$ & 54.59 & 54.33 & 54.13 \\
EE & $63.39^{\mathrm{b}}$ & $77.77^{\mathrm{a}}$ & $81.70^{\mathrm{a}}$ & $76.30^{\mathrm{b}}$ & $86.74^{\mathrm{a}}$ & $85.98^{\mathrm{a}}$ \\
NFE & 73.32 & 74.90 & 77.16 & $67.02^{\mathrm{b}}$ & $70.99^{\mathrm{a}}$ & $73.69^{\mathrm{a}}$ \\
\hline Nutritive values (\%): & $62.59^{\mathrm{c}}$ & $68.45^{\mathrm{b}}$ & $71.99^{\mathrm{a}}$ & $59.23^{\mathrm{c}}$ & $66.30^{\mathrm{b}}$ & $68.86^{\mathrm{a}}$ \\
\hline TDN & 9.90 & 10.38 & 10.63 & $8.18^{\mathrm{b}}$ & $8.92^{\mathrm{a}}$ & $8.86^{\mathrm{a}}$ \\
\hline
\end{tabular}

a, b and c: Means within the same row with different superscripts for each feeding system are significantly different at $(P<0.05)$.

El-Sanafawy (2008) found that inclusion of SFS at levels of 5 or $10 \%$ did not affect digestibility coefficients of nutrients, except that of EE, which significantly $(\mathrm{P}<0.05)$ improved with rations containing both SFS levels during winter or summer feeding as compared to the control ration. The present results herein indicated beneficial effects of increasing dietary level of SFS more than $10 \%$ on digestibility coefficients, whereas increasing level of SFS to 15 or $20 \%$ significantly $(P<0.05)$ increased most nutrients in particular during summer feeding. However, Aboul-Fotouh et al. (1999) concluded that when SFS was used to replace $30 \%$ of CFM (representing $12 \%$ of total DM), digestibility coefficients of nutrients and nutritive values (TDN and DCP) were not significantly affected by oil seeds inclusion, which may suggest that increasing dietary level of SFS up to $30 \%$ may have adverse effects on digestion within the rumen. However, Park et al. (1983) found that increasing whole SFS $(0,10,20$ and $30 \%)$ in rations improved digestibility of dietary components fed to Holstein heifers.

On the other hand, no differences in digestion of DM or CP were found between growing calves fed SFM or SBM (Richardson et al., 1981). 
Also, Anderson et al. (1984) reported that DM digestibility was not significantly differed among cows fed rations contained $10 \%$ whole cotton seeds, $5 \%$ extruded soybean or $12 \%$ whole sunflower seeds. Moreover, Drackley et al. (1985) found that digestibility coefficients of DM, OM, CP and EE did not significantly differ for steers fed diet contained soybean meal + sunflower seeds plus calcium hydroxide compared to those fed soybean meal + sunflower seeds plus limestone.

In accordance with the present results on goats, Zhang et al. (2007) reported that oilseed supplementation had no effect on total tract fiber digestibility of lactating ewes. Ewes fed SFS had a higher $(\mathrm{P}<0.05)$ DM digestibility than those fed canola seed (CS) or control. El-Bedawy et al. (1994) found that feeding full fat sunflower or sunflower oil plus sunflower meal rations increased $(P<0.05)$ cow digestibility of $E E$ but had no significant effect on the other nutrient digestibility's. Aboul-Fotouh (1995) reported that oil seed supplemented diets tended to be higher in EE digestibility than other diets. The observed improve in digestibility coefficients of SFS rations as compared to the control may suggest that oilseeds are potential feed ingredients to control protozoa populations in ruminants and to increase the efficiency of dietary protein utilization (Ivan et al., 2001).

\section{Rumen liquor parameters:}

Data in Table (3) show that inclusion of SFS at both levels (15 and $20 \%)$ in rations of goats during winter feeding significantly $(P<0.05)$ increased $\mathrm{pH}$ value and decreased concentration of VFAs, but did not affect ammonia concentration in ruminal liquor $(R L)$ sampled before or post-feeding. On the other hand, only inclusion of SFS at a level of $20 \%$ in rations of goats during summer feeding significantly $(\mathrm{P}<0.05)$ decreased $\mathrm{pH}$ value and concentration of VFAs but increased ammonia concentration in $R L$ sampled before or postfeeding.

Table (3): Effect of feeding experimental rations on rumen liquor parameters at each of sampling time.

\begin{tabular}{|c|c|c|c|c|c|c|}
\hline \multirow{2}{*}{ Time (h) } & \multicolumn{3}{|c|}{ Winter feeding } & \multicolumn{3}{|c|}{ Summer feeding } \\
\hline & $\mathbf{G}_{1}$ & $\mathbf{G}_{2}$ & $\mathbf{G}_{3}$ & $\mathbf{G}_{1}$ & $\mathbf{G}_{2}$ & $\mathbf{G}_{3}$ \\
\hline \multicolumn{7}{|c|}{ Ruminal pH value: } \\
\hline $0 \mathrm{~h}$ & 7.25 & 7.35 & 7.26 & 7.19 & 7.34 & 7.32 \\
\hline $3 \mathrm{~h}$ & $6.18^{b}$ & $6.69^{a}$ & $6.65^{\text {ab }}$ & $6.76^{\mathrm{a}}$ & $6.31^{\mathrm{ab}}$ & $6.08^{b}$ \\
\hline $6 \mathrm{~h}$ & $6.34^{b}$ & $7.79^{\mathrm{a}}$ & $6.51^{\text {ab }}$ & $6.89^{\mathrm{ab}}$ & $6.93^{\mathrm{a}}$ & $6.83^{b}$ \\
\hline \multicolumn{7}{|c|}{ Concentration of VFAs (meq/100 ml): } \\
\hline $0 \mathrm{~h}$ & $14.50^{\mathrm{a}}$ & $11.40^{\mathrm{b}}$ & $10.82^{b}$ & $11.64^{\mathrm{a}}$ & $9.41^{\mathrm{b}}$ & $9.27^{b}$ \\
\hline $3 \mathrm{~h}$ & $18.15^{a}$ & $16.56^{\mathrm{b}}$ & $14.86^{\mathrm{C}}$ & $16.53^{\mathrm{a}}$ & $13.77^{b}$ & $13.55^{\mathrm{b}}$ \\
\hline $6 \mathrm{~h}$ & $16.40^{\mathrm{a}}$ & $14.71^{\mathrm{b}}$ & $12.67^{\mathrm{C}}$ & $14.51^{\mathrm{a}}$ & $10.95^{b}$ & $10.57^{b}$ \\
\hline \multicolumn{7}{|c|}{ Ruminal $\mathrm{NH}_{3}-\mathrm{N}$ concentration $(\mathrm{mg} / 100 \mathrm{ml})$ : } \\
\hline $0 \mathrm{~h}$ & 21.09 & 21.48 & 22.40 & 19.13 & 19.41 & 21.09 \\
\hline $3 \mathrm{~h}$ & 25.57 & 26.02 & 27.06 & $22.12^{b}$ & $23.80^{\mathrm{a}}$ & $24.59^{a}$ \\
\hline $6 \mathrm{~h}$ & 20.80 & 21.40 & 21.65 & $19.88^{b}$ & $21.18^{\mathrm{a}}$ & $21.46^{\mathrm{a}}$ \\
\hline
\end{tabular}

a, $b$ and $c$ : Means within the same row with different superscripts for each feeding system are significantly different at $(P<0.05)$.

Generally, all rumen parameters studied showed similar trend of change in all groups with sampling times. Considering the trend for some 
rumen parameters at 0,4 and $7 \mathrm{~h}$ post-feeding, it can be noticed that acetate and propionate were increased in rumen fluid at 4 and $7 \mathrm{~h}$ after feeding, while $\mathrm{pH}$ and ammonia tended to decrease by $4 \mathrm{~h}$ after feeding (Badamana and Sutton, 1992). Based on these results, inclusion of SFS by both levels adversely affected $\mathrm{pH}$ and VFAs production in rations containing $\mathrm{FB}$ or $\mathrm{BH}$. However, dietary inclusion of $20 \%$ SFS significantly $(P<0.05)$ increased ammonia concentration with diets contained $\mathrm{BH}$.

In this respect, Jenkins (1993) reported that vegetable oil often depress animal fiber digestion. Also, the present results showed insignificant effect of SFS diets on CF digestibility coefficients during winter and summer feeding. In accordance with the present results, El-Sanafawy (2008) on zaraibi goats, revealed that diets contained sunflower seed at 5 or $10 \%$ reduced $\mathrm{pH}$ value of rumen liquor $(\mathrm{RL})$ to 6.59 and 6.41 as compared to 7.10 in the control, respectively. However, concentration of ammonia- $\mathrm{N}$ increased to 23.42 and $24.32 \mathrm{mg} / 100 \mathrm{ml} \mathrm{RL}$ as compared to $22.31 \mathrm{mg} / 100 \mathrm{ml} \mathrm{RL}$ in the control, respectively. Yet, concentration of VFA decreased to 14.68 and 13.86 $\mathrm{meq} / 100 \mathrm{ml} \mathrm{RL}$ as compared to $16.60 \mathrm{meq} / 100 \mathrm{ml} \mathrm{RL}$ in the control. Such findings may indicate marked effect of SFS as a source of protein and energy rather than their levels on rumen fermentation. These findings could be explained by the negative effect of free fatty acids on fermentation, which might be attributed to defaundation that could increase duodenal bacterial- $\mathrm{N}$ flow by decreasing protozoal predation of ruminal bacteria and competition for substrates between these microorganisms (Jopuany and Ushida, 1999 and Khattab et al., 2001). Fierez et al. (2003) and Boeckaert et al. (2004) found that the reduction in TVFA's concentration might be due to lower cellulose digestibility. Also, Kitessa et al. (2001) and Jones et al. (2003) reported that a reduction in TVFA's could also be related to the reduced feed intake. Kucuk et al. (2004) reported that total ruminal VFA concentrations changed (cubic, $P=0.01$ ) with increased dietary soybean oil by decreasing by $7.4 \%$ when soybean oil was increased from 0 to $3.2 \%$, then increasing by $20.5 \%$ when soybean oil was increased to $6.3 \%$, and finally decreasing by $32.2 \%$ when dietary soybean oil was increased to $9.4 \%$. The most pronounced effects on VFA concentration occurred with the $6.3 \%$ soybean oil diet.

\section{Live body weight:}

Data presented in Table (4) show that the differences in live body weight (LBW) among the experimental groups were not significant at late pregnancy ( $30 \mathrm{~d}$ pre-partum), during suckling period $(0-90 \mathrm{~d}$ post-partum) and even during milking period (90-225 d). Also, there was a similar trend of changes in LBW of does within each group at different experimental periods. Does in all groups showed marked reduction in LBW between $30 \mathrm{~d}$ prepartum and $15 \mathrm{~d}$ postpartum. The sharp decrease in LBW resulted from kidding and removal of fetus and its attachments (embryonic membranes and fluids). Similar to the present results, the negative correlation between milk production and body weight changes was reported on Zaraibi does fed diets supplemented with different types of calcium salt fatty acids (CSFA) (Hassan et al., 2012) or fed diets contained 5 or $10 \%$ SFS. 
Table (4): Effect of feeding experimental rations on live body weight $(\mathrm{kg})$ of does during pre- and post-partum and milking periods (means \pm SE) .

\begin{tabular}{|c|c|c|c|c|}
\hline \multirow{2}{*}{ Period } & \multicolumn{3}{|c|}{ Experimental group } & \multirow{2}{*}{ P-value } \\
\hline & $\mathbf{G}_{1}$ & $\mathbf{G}_{2}$ & $\mathbf{G}_{3}$ & \\
\hline \multicolumn{5}{|l|}{ Pre-kidding } \\
\hline $30 \mathrm{~d}$ pre-partum & $47.2 \pm 1.71$ & $48.0 \pm 1.63$ & $48.8 \pm 1.20$ & 0.481 \\
\hline \multicolumn{5}{|c|}{ Post-partum period (suckling period): } \\
\hline 15 days & $36.0 \pm 1.55$ & $37.8 \pm 2.13$ & $38.0 \pm 2.70$ & 0.127 \\
\hline 30 days & $35.8 \pm 1.37$ & $37.5 \pm 1.86$ & $37.7 \pm 1.07$ & 0.916 \\
\hline 45 days & $34.5 \pm 1.15$ & $36.9 \pm 1.47$ & $36.3 \pm 1.66$ & 0.927 \\
\hline 60 days & $35.4 \pm 0.66$ & $37.0 \pm 1.53$ & $37.7 \pm 1.10$ & 0.369 \\
\hline 75 days & $35.3 \pm 1.12$ & $37.5 \pm 1.87$ & $38.4 \pm 0.69$ & 0.530 \\
\hline $90 \mathrm{~d}$ (weaning) & $34.3 \pm 1.19$ & $37.1 \pm 1.50$ & $38.6 \pm 1.07$ & 0.417 \\
\hline \multicolumn{5}{|l|}{ Milking period: } \\
\hline 120 days & $35.0 \pm 1.05$ & $37.4 \pm 1.44$ & $38.2 \pm 1.03$ & 0.561 \\
\hline 135 days & $34.0 \pm 1.22$ & $36.0 \pm 1.36$ & $38.4 \pm 0.92$ & 0.339 \\
\hline 150 days & $34.9 \pm 1.29$ & $36.1 \pm 1.47$ & $38.2 \pm 0.90$ & 0.274 \\
\hline 165 days & $34.2 \pm 1.24$ & $36.3 \pm 1.07$ & $37.3 \pm 0.91$ & 0.997 \\
\hline 180 days & $33.7 \pm 1.15$ & $35.4 \pm 1.77$ & $38.3 \pm 0.93$ & 0.577 \\
\hline 195 days & $34.8 \pm 1.20$ & $36.0 \pm 1.55$ & $38.7 \pm 0.75$ & 0.679 \\
\hline 210 days & $35.8 \pm 1.48$ & $36.8 \pm 1.38$ & $38.7 \pm 0.90$ & 0.564 \\
\hline 225 days & $37.6 \pm 1.32$ & $38.1 \pm 1.43$ & $39.7 \pm 0.95$ & 0.803 \\
\hline
\end{tabular}

Also, Zambom et al. (2003) revealed a 16.42 to $20.72 \%$ reduction in body weight of ewes had occurred after lambing. However, during suckling and milking periods, they severed from slight loss in LBW due to milk production. During the physiological stress of milk production particularly during the peak of lactation, goats tended to have no increase or may loss of body weight (Dapoza et al., 1999 and Olsson et al., 1999). They indicated that animals did not gain weight or may lose weight during lactation, especially up to peak of lactation. Morand-Fehr et al. (1992) had already analyzed variations in body reserves in goats during a cycle of reproductive and during the growth period, methods of assessing them, the relationships between body condition and goat performance and various uses of body conditions. A body condition score method based on body palpations is difficult to work out in goats because of a lack of subcutaneous adipose tissue in this species. Djibrillou et al. (1998) observed continued loss of body weight in goats throughout lactation in Red Sokoto goat in Niger Republic, and cotton seed supplementation did not prevent weight loss throughout eight-week long lactation. Recently, Otaru et al. (2011) found that the weight loss of goats was numerically more with higher levels of palm oil supplementation which might have been due to lower DM and hay intake.

In accordance with the present results in other species, Richardson et al. (1981) found no differences in growth performance between growing calves fed SFM or SBM. In ewes, El-Shahat and Abo-El Maaty (2010) identified that dietary supplementation of CSFA enhanced body growth as indicated by increased final body weight and body condition score. However, Purushothaman et al. (2008) found non-significant effect of feeding ration containing palm oil on average adjusted values for body weight gain/day. In cows, Schauff and Clark (1989) observed similar weight loss and attributed it 
to decreased DM intake, while in ewes; it was associated with decreased forage intake (Casals et al., 2006).

It could be concluded that replacing $20 \%$ of CFM by sunflower seeds has beneficial effects on digestibility coefficient and nutritive values without marked change in ruminal liquor parameters and goat performance in Zaraibi lactating goats.

\section{REFERENCES}

Aboul-Fotouh, G. E. (1995). Effect of some medicinal plants as feed additives on performance of growing sheep. Egyptian J. Nutrition and Feeds, 2 (2): 79-87.

Aboul-Fotouh, G. E.; Allam, S. M. and El-Gharhy, G. M. (1999). Effect of feeding whole cotton and sunflower oilseeds on lactation performance of buffaloes. Egypt. J. Anim. Prod., 36 (2): 93-102.

Ahmed, I.; Javed, K.; Mirza, R.H.; Sattar, A. and Ahmad, F. (2004). Effect of feeding sunflower meal as a substitute of cottonseed cake on growth and age of maturity in Holstein Friesian heifers. Pakistan Veterinary Journal, 24 (2): 95-97.

Anderson, M. J.; Obadiah, Y.E.M.; Boman, R.L. and Walters, J.L. (1984). Comparison of whole cottonseed, extruded soybeans, or whole sunflower seeds for lactating dairy cows. J. Dairy Sci., 67: 569-573.

Antunac, N.; Samarsija, D.; Havranek, J.L.; Pavic, V. and Mioc, B. (2001): Effect of stage and number of lactation on chemical composition of goat milk. Czech. J. Animal Sci., Uzpi (Czech Republic), 46 (12): 548553.

AOAC (1990). Official methods of analysis, $14^{\text {th }}$ ed. Association of Official Analytical Chemists. Washington DC.

Arain, M.A.; Khaskheli, M.; Rajput, I.R.; Rao, S. and Faraz, S. (2010). Examination of physical properties of goat meat. Pakistan Journal of Nutrition, 9 (5): $422-425$.

Badamana, M. S. and Sutton, J. D. (1992). Hay intake, milk production and rumen fermentation in British Saanen goats given concentrates varying widely in protein concentration. Anim. Prod., 54: 395-403

Boeckaert, C.; Mestdagh, J.; Clayton, D. and Fievez, V. (2004). Microalgae as a potent rumen methane inhibitors and modifiers of rumen lipolysis and biohydrogenation of linoleic acid. Communications in Agricultural and Applied Biological Sciences, 69 (2): 127-136.

Casals, R.; Caja, G.; Pol, M. V. ; Such, X.; Albanell, E. ; Gargouri, A. and Casellas, J. (2006). Response of lactating dairy ewes to various levels of dietary calcium soaps of fatty acids. Anim. Feed Sci. and Technol., 131: 312-332.

Chiduza, C.; Waddington, S.R. and Rukuni, M. (1995). Evaluation of sorghum technologies for smallholders in a semi-arid region of Zimbabwe (Part II): Sorghum varieties against fertilizer trials. Journal of Applied Science in Southern Africa, 1:11-22. 
Conway, E. G. and O'Malley, M. S. (1957). Microdiffusion Analysis and Volumetric Error. $4^{\text {th }}$ Ed. O. Grasphy-Lock wood and Sons Ltd., London.

Dapoza, C.; Castrillo, C.; Balcells, J.; Martin-Orue, S. and Guada, J. A. (1999). On the variation of urinary excretion of creatinine and purine derivations in pregnant and lactating ewes given diets with different protein contents.J. Anim. Sci., 68: 555-566.

Djibrillou, O. A.; Pandey, V.S.; Gouro, S.A. and Andverhulst, A. (1998). Effect of urea-treated or untreated straw with cotton seed on performances of lactating Maradi (Red Sokoto) goats in Niger. Institute National De La Recherche Agronomique Du Niger, B.P. 429-438.

Drackley, J. K.; Clarck, A. K. and Sahlu, T. (1985). Ration digestibility and ruminal characteristics in steers fed sunflower seeds with additional calcium soaps on rumen and total nutrient digestibility of dairy rations. J. Dairy Sci., 67: 367-378.

El-Bedawy, T. M.; El-Husseini, H. M.; Allam, S. M. and Shahin, F. H. (1994). Effect of dietary fat and calcium supplements on in vivo digestibility, rumen fermentation and some blood constituents of sheep. Egypt. J. Anim. Prod., 31: 59-73.

El-Hassan El-Abid, K.; Babikerb, S. A. and Abu Nikhaila, A.M.A. (2008). Growth rates of Sudanese Nubian kids under small holder system. Inter. J. Dairy Sci., 3: 170-178.

El-Sanafawy, H. A. (2008). Performance of goats fed on rations containing whole sunflower seeds. M. Sc. Thesis, Fac. Agric., Kafer El-Sheikh Univ.

El-Shahat, K. H. and Abo-El maaty, A. M. (2010). The effect of dietary supplementation with calcium salts of long chain fatty acids and/or Icarnitine on ovarian activity of Rahmani ewes. Anim. Reprod. Sci., 117 (1): 78-82.

Fierez, V.; Dohme, F.; Danneels, M.; Raes, K. and Demeyer, D. (2003). Fish oils as potent rumen methane inhibitors and associated effects on rumen fermentation in vitro and in vivo. J. Anim. Feed Sci. Technology, $104(1 / 4): 41-55$.

Gaddour A.; Najari, S. and Ouni, M. (2007). Kid's Growth and dairy performances of pure breeds and crossed Caprine genotypes in the Coastal Oases of Southern Tunisia. Pakistan Journal of Biological Science, 10 (17): 2874-2879.

Garcia, J.A.; de F. Vieira S.P.; Cecon, P.R.; de Melo, G.M.P.; de S. Martins A. and Stti, M. C. (2004). Apparent digestibility of sunflower meal in growing dairy cattle feeding. Ciencia Anim. Brasileira, 5 (3): 123-129.

Grummer, R. R. and Carroll, D. J. (1988). A review of lipoprotein cholesterol metabolism. Importance to ovulation function. J. Anim. Sci., 66: 31603172.

Hassan, T.M.; Ibrahim, M., Itman, K. and Abdel-Hai, I (2012). Productive and reproductive performance of Zaraibi goats fed different types of protected fat. The $3^{\text {rd }}$ Scientific Conference for Animal Nutrition, Sharm El-Sheikh, 14-17 Feb.(under publication). 
Ivan, M.; Mir, P. S.; Koenig, K. M.; Rode, L. M. ; Neill, L.; Entz, T. and Mir, Z. (2001). Effects of dietary sunflower seed oil on rumen protozoa population and tissue concentration of conjugated linoleic acid in sheep. Small Rum. Res., 41: 215-227.

Jenkins, T. C. (1993). Lipid metabolism in the rumen. J. Dairy Sci., 76: 38513863.

Jones, D. F.; Weiss, W. P. and Jenkins, T. C. (2003). Dietary fish oil for dairy cows: 2-effects on neutrophil function and digestibility. Res. and Rev. Dairy, 163: 99-115.

Jopuany, J. P. and Ushida, K. (1999). The role of rumen protozoa in feed digestion. Asian-Aust. J. Anim. Sci., 12: 113-126.

Khattab, H. M.; El-Sayed, H. M.; El-Ashry, M. A.; Gomaa, I. M. and Omar, F. M. (2001). Performance of fattening lambs fed rations containing different levels of soylecithin and sunflower soap stock as non conventional fats. 1- Effect of nutrients digestibility, nitrogen and water balance. Egyptian J. Nutr. and Feeds, 4: 667-680.

Kibria, S. S.; Islam, M. R. and Shah, C. K. (1991). Development of straw based ration for feeding ruminants. Asian-Aust. J. Anim. Sci., 4: 235240.

Kitessa, S. M. ; Gulati, S. K. ; Ashes, J. R. ; Fleck, E. ; Scott, T. W. and Nichols, P. D. (2001). Utilization of fish oil in ruminants. II. Transfer of fish oil fatty acids into goat's milk. Anim. Feed Sci. and Technology, 89: 201-208.

Kucuk, O.; Hess, B. W. and Rule, D. C. (2004). Soybean oil supplementation of a high-concentrate diet does not affect site and extent of organic matter, starch, neutral detergent fiber, or nitrogen digestion, but influences both ruminal metabolism and intestinal flow of fatty acids in limit-fed lambs. J. Anim. Sci., 2004. 82: 2985 - 2994.

Landau, S.; Kababya, D.; Perevololotsky, A.; Gilboa, N.; Silanikove, N. and Nitsan, Z. (1995). Complémentation de chèvres laitières sur parcours méditerranéens semi-arides. Renc. Rech. Ruminant, 2: 55-60.

Lardy, G. P. and Anderson, V. (2002). Canola and sunflower meal in beef cattle diets. Vet. Clinics of North America: Food Animal Practice, 18: 327-338.

Min, B. R.; Hart, S. P.; Sahlu, T. and Satter, L. D. (2005). The effect of diets on milk production and composition, and on lactation curves in Astured dairy goats. J. Dairy Sci., 88: $2604-2615$.

Morand-Fehr, P.; Amaro, R.P.; Rubino, R.; Branca, A.; Santucci, P.M. and Hadjipanayitou, M. (1992). Assessment of goat body condition and its use for feeding management. In: Proceedings of the $5^{\text {th }}$ International Conference on Goats, vol. 2, part 1, New Delhi, India, 2-8 March 1992, pp. 212-223.

Mousa, M.R.M. (2011). Effect of partial replacement of dietary concentrate feed mixture by fodder Beet roots on productive performance of Ewes and doe goats under the conditions of North Sinai. Asian Journal of Animal Science, 5(4): 228-242. 
Norton, B.W.; Lowry, B. and Mc Sweeney, C. (1994). The nutritive value of Leucaena species. Presented at Int. Workshop on Leucaena R\&D Bogor - Indonesia 24-29 Jan.

NRC (2001). Nutrient Requirements of Dairy Cattle. 7th Rev. ed. National Academy Press, Washington, DC.

Olsson, G.; Bergsten, C. and Wiktorsson, H. (1999). The influence of diet before and after calving on the food intake, production and health of primiparous cows, with special reference to sole haemorrhages. Anim. Sci., 66: 75-83.

Otaru, S. M.; Adamu, O. W.; Ehoche, O. W. and Makun, H. J. (2011). Effects of varying the level of palm oil on feed intake and milk yield and composition and postpartum weight changes of Red Sokoto goats. Small Rumin. Res., 96:25-35.

Park, C. S.; Rafalowski, W. and Marx, G. D. (1983). Effect of dietary fat supplement of lipid metabolism of Holstein heifer. J. Dairy Sci., 66: 528.

Purushothaman, S.; Anil K. and Tiwari, D. P. (2008). Effect of Feeding Calcium Salts of Palm Oil Fatty Acids on Performance of Lactating Crossbred Cows. Asian-Aust. J. Anim. Sci., 21 (3): 376 - 385.

Richardson, R.C.; Beville, N.R.; Ratcliff, K.R. and Albin, C.R. (1981). Sunflower meal as a protein supplement for growing ruminants. J. Anim. Sci., 53 (3): 557-563.

Schauff, D. J.; Elliott, J. D.; Clark, J. H. and Darckly, T. K. (1992). Effects of feeding lactating dairy cows diets containing whole soybeans and tallow. J. Dairy Sci., 75: 1923-1945.

Schauff, D. J. and Clark, J. H. (1989). Effects of prilled fatty acids and calcium salts of fatty acids on rumen fermentation, nutrient digestibilities, milk production, and milk composition. J. Dairy Sci., 72 : 917-927.

SPSS (2004). Statistical Package for Social Science (SPSS). Release 13.0. The Apasche software foundation for windows.

Van Keulen, J. and Young, B. A. (1977). Evaluation of acid insoluble ash as a natural marker in ruminant digestibility studies. J. Anim. Sci., 44 (2): 282-287.

Warner, A. C. I. (1964). Production of volatile fatty acid in the rumen, methods of measurements. Nutr. Abst. and Rev., B. 34: 339.

Yagoub, M.Y. and Babiker, S.A. (2009). Effect of compensatory growth on performance of Sudanese female goats. Pakistan Journal of Nutrition, 8 (11): 1802-1805.

Yunus, A. W.; Khan, A. G.; Alam, Z.; Sultan, J. I. and Riaz, M. (2004). Effect of substituting cottonseed meal with sunflower meal in rations for growing buffalo calves. Asian- Aust. J. Anim. Sci., 17: 659-662.

Zahid, I.A.; Lohdi, L.A.; Ahmed, N.; Rehman, N.U. and Akhtar, M.S. (2003). Effects of cotton seed cake (gossypol) on live weight of teddy male goats. Pakistan Veterinary Journal, 23: 27-30. 
Zambom, M. A. ; Alcalde, C. R. ; Macedo, F. A. F. ; Gavcia, J. ; Silva, K. T. ; Martins, E. N. and Sontos, G. T. (2003). Performance and quality of milk of Saanen goats feeding with different roughage concentrations, in the prepartum and lactation from CD of IX world conference on animal production., Oct. 26-31, Porto Alegre ,Rio Grande Do Sul, Brazil.

Zhang, R.H; Mustafa, A.F. and Zhao, X. (2007). Effects of feeding oilseeds on nutrient utilization by lactating ewes. Small Rumin. Res., 67: 307311.

تأثير التغذية على بذور دوار الثمس الكاملة للماعز الزرايبى الحلابة:

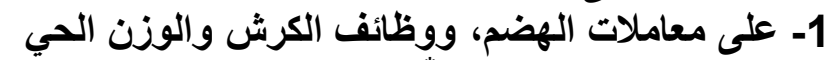

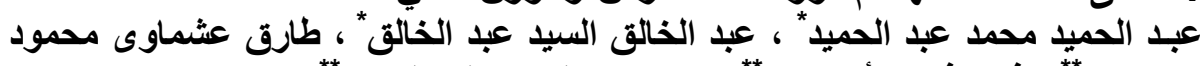

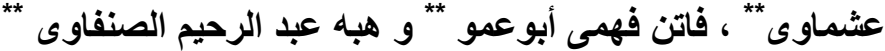

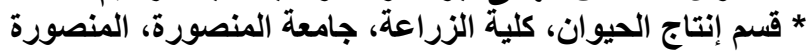
* * معه بحوث الإنتاج الحيوانى، مركز البحوث جامعة الزراعية

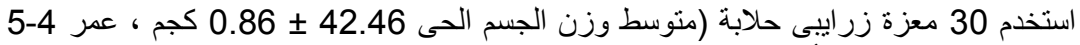

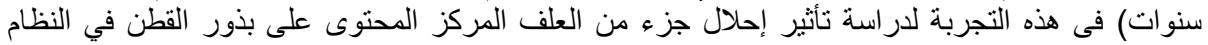

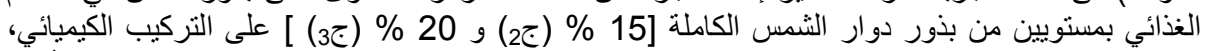

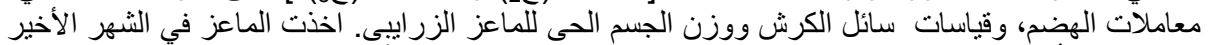

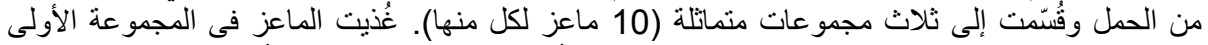

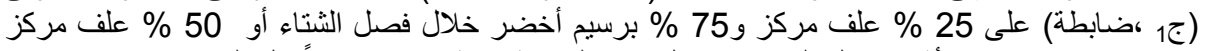

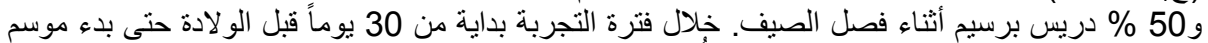

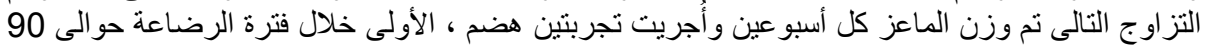

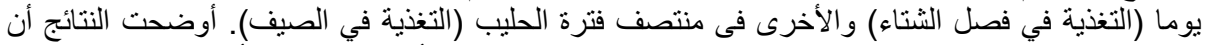

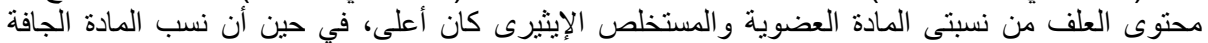

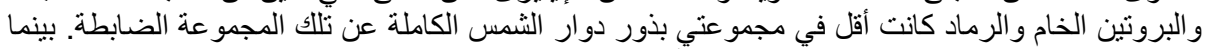

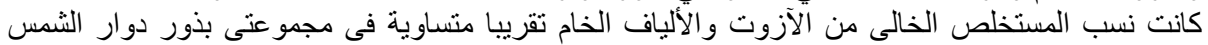

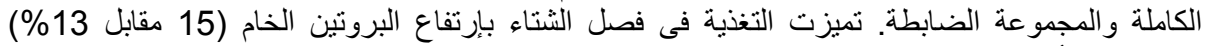

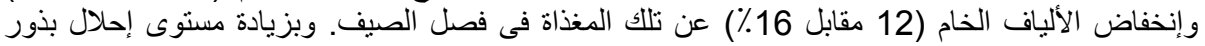

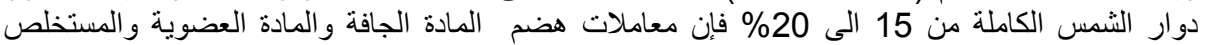

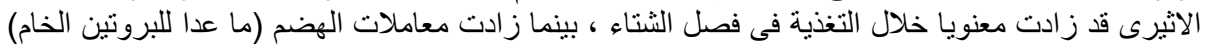

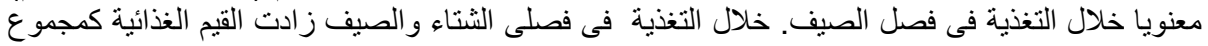

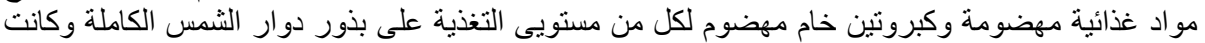

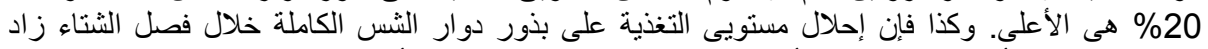

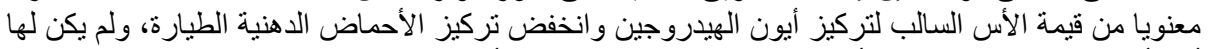

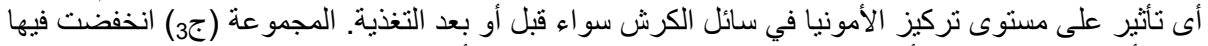

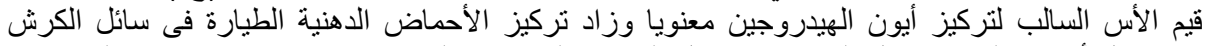

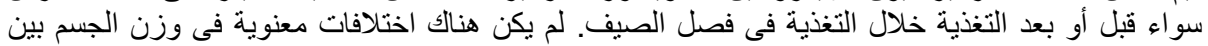

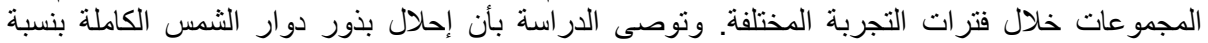

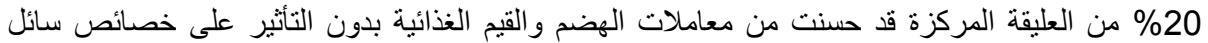
الكرش و أداء الماعز الزر اييى الحلابة.

كلية الزراعة - جامعة المنصورة كلية الزراعة - جامعة كفر الثيخ

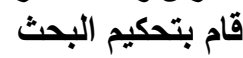

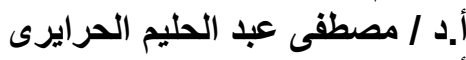
أ.د / سعيد احمد محمود إلد الديم 